\title{
S.N.H.S. ANNUAL MEETING
}

\section{Saskatoon, October 15-16, 1965}

Place: University of Saskatchewan, Saskatoon

\section{Friday Evening Programme October 15}

Registration: Beginning at 7:30 p.m., in Convocation Hall, University Campus. Registration fee for adults - \$1.00. Children - no charge. Saturday dinner tickets extra.

Reception for members and friends. Time: 8:30 p.m. Hosts: Saskatoon Natural History Society.

\section{Saturday Programme October 16}

Early morning bird trip: Meet at the Visitors' Parking Lot, University Hospital, at 7:00 a.m.

Registration (continued): From 9:00 a.m. through the morning. Please arrange for dinner tickets.

Business Session: 9:30 to 12:00 noon.

Recess for lunch: $12: 00$ to $1: 30$.

Programme Session: $1: 30$ to $5: 00$, with coffee available at $3: 15$.

\section{NOMINATIONS AND RESOLUTIONS}

Nominations and Resolutions should be sent to the Recording Secretary, Mr. James Slimmon, 2526 Hanover Ave., Saskatoon. Please give thought to the resolutions and forward them in advance of the meeting.
Dinner: Place to be announced. Tickets at registration desk. Time: 6:30 p.m.

Evening Address: Address by guest speaker at 8:00. Public invited.

\section{NOTE RE:}

\section{MEMBERS' CONTRIBUTIONS}

Members with kodachromes are invited to notify the Programme Committee, c/o Mr.. James Slimmon, 2526 Hanover Ave., Saskatoon, by October 1 , so that an hour of slides can be arranged for Saturday afternoon.

FOR FURTHER INFORMATION write to Mr. James Slimmon, 2526 Hanover Ave., who will pass your inquiries on to the Committee of the Saskatoon Natural History Society who is making arrangements for the programme.

\section{NOTICE OF MOTION}

At the Executive Meeting, April 10,1965 , it was agreed to give the following notice of motion in the September Blue Jay, as required by the constitution:

Moved that the following scale of SNHS membership fees be adopted:

Adult -1 year, $\$ 3.00 ; 2$ years, $\$ 5.00$; 3 years, $\$ 6.00$.

Junior -1 year, $\$ 2.00 ; 2$ years, $\$ 3.00$. 